\title{
GAMBARAN KANDUNGAN KALSIUM URINE PADA WANITA LANJUT USIA DI JALAN BALANG BARU MAKASSAR
}

\author{
Mardiah $^{1)}$ \\ 1)Akademi Analis Kesehatan Muhammadivah Makassar \\ Alamat Korespondensi: mardiah.diomks77@gmail.com
}

\begin{abstract}
Abstrak
Kalsium adalah mineral yang paling banyak terdapat di dalam tubuh berhubungan dengan sejumlah mekanisme fisiologi tubuh. Kalsium berperan sebagai proses pembentukan tulang dan gigi, dan mencegah osteoporosis pada wanita lanjut usia. Tujuan penelitian ini adalah untuk mengetahui besarnya ekskresi kalsium melalui urine wanita lanjut usia di Jl.Balang Baru Makassar. Penelitian ini bersifat deskriptif dimana sampel diambil secara Purposive sampling berdasarkan pertimbangan umur. Pemeriksaan gambaran kalsium urine menggunakan metode Sulkowitch. Hasil penelitian menunjukkan bahwa dari 10 sampel urine wanita lanjut usia diperoleh diperoleh 6 orang memiliki kalsium urine normal dan 4 orang lainnya memiliki ekskresi kalsium hiperkalsiuria (eksresi kalsium tinggi). Dari penelitian ini dapat disimpulkan bahwa 60\% wanita yang telah lanjut usia orang menunjukkan ekskresi kalsium normal, dan $40 \%$ wanita yang telah lanjut usia menunjukan ekskresi kalsium tinggi.
\end{abstract}

Kata Kunci: Kalsium, Metode Sulkowitch, Urine Wanita Lanjut Usia

\section{PENDAHULUAN}

Tubuh mengandung lebih banyak kalsium dari pada mineral lain. Diperkirakan $2 \%$ berat badan orang dewasa atau sekitar $1,0-1,4 \mathrm{~kg}$ terdiri dari kalsium. Meskipun pada bayi kalsium hanya sedikit (25-30 g), setelah usia 20 tahun secara normal akan terjadi penempatan sekitar $1.200 \mathrm{~g}$ kalsium dalam tubuhnya. Sebagian besar kalsium terkonsentrasi dalam tulang rawan dan gigi, sisanya terdapat dalam cairan tubuh dan jaringan lunak (Winarno, 1984).

Semakin bertambahnya umur manusia, terjadi proses penuaan secara degenerative yang akan dampak pada perubahan-perubahan pada diri manusia. Perubahan-perubahan yang terjadi pada lanjut usia dapat dinilai juga pada sistem perkemihan.

Pada sistem perkemihan lanjut usia terjadi perubahan yang signifikan. Banyak fungsi yang mengalami kemunduran, contohnya laju filtrasi, ekskresi, dan reabsorpsi oleh ginjal. Hal ini akan memberikan efek dalam pemberian obat pada lanjut usia. Mereka kehilangan kemampuan untuk mengekskersi obat atau produk metabolisme obat. Pola berkemih tidak normal, seperti banyak berkemih di malam hari, sehingga mengharuskan mereka pergi ke toilet sepanjang malam. Penyakit metabolik pada lanjut usia terutama disebabkan menurunnya produksi hormon, antara lain terlihat pada wanita mendekati usia 50 tahun, yang ditandai mulainya menstruasi yang tidak teratur sampai berhenti sama sekali (menopause), prosesnya merupakan proses alamiah. Penyakit metabolik yang banyak dijumpai ialah diabetes mellitus atau kencing manis dan osteoporosis (berkurangnya zat kapur dan bahan-bahan mineral sehingga tulang lebih mudah rapuh dan menipis).

Selain penyakit pada gangguan kelenjar endokrin ada pula penyakit yang sering diderita lansia yaitu penyakit persendian dan tulang. Penyakit pada sendi ini adalah akibat degenerasi atau kerusakan pada permukaan sendi-sendi tulang yang banyak dijumpai pada lanjut usia terutama yang gemuk.

Terjadinya osteoporosis ini menyebabkan tulang-tulang lanjut usia mudah patah sehingga akan sulit sembuhnya. Biasanya patah tulang terjadi karena lanjut usia tersebut jatuh. Jatuhnya dapat terjadi karena sudah berkurangnya kekuatan otot-otot, berkurangnya koordinasi kekuatan anggota badan secara 
keseluruhan, medadak pusing, penglihatan yang kurang baik (Azizah, 2011).

Tulang merupakan jaringan pengikat yang sangat khusus bentuknya. Tulang dibentuk dalam dua proses yang terpisah, yaitu pembentukan matriks dan penempatan mineral kedalam matriks tersebut. Tiga komponen seluler terlibat didalamnya dengan fungsi yang berbeda beda yaitu osteoblast dalam pembentukan tulang, osteocyte dalam pemeliharaan tulang, dan osteoclast dalam penyerapan kembali tulang. Osteoblast membentuk kolagen tempat mineral-mineral melekat. Mineral utama di dalam tulang adalah kalsium dan fosfor, sedangkan mineral lain dalam jumlah kecil adalah natrium, magnesium, dan flour (Winarno, 1984).

Dari uraian latar belakang, maka ditemukan rumusan masalah yaitu apakah terdapat kalsium rine pada wanita anjut usia?

Penelitian ini bertujuan untuk mengetahui kandungan kalsium urine wanita lanjut usia.

\section{METODE PENELITIAN}

\section{Alat dan Bahan}

Alat yang digunakan adalah botol urine, tabung reaksi, rak tabung, dan pipet tetes.

Bahan yang digunakan adalah urine 24 jam, asam sulfat pekat (pengawet urine), reagen Sulkowitch (asam oksalat $2,5 \mathrm{~g}$, amoniumoxalat 2,5 g, asam acetat glacial 5,0 ml, dan aquadest $150 \mathrm{ml}$ ).

\section{Prosedur Kerja \\ Pengambilan sampel}

Untuk mengumpulkan Urine 24 jam diperlukan botol yang besar, wadah bervolume $1 \frac{1}{2}$ liter atau lebih yang dapat ditutup dengan baik dan telah diisi pengawet urine pada botol tersebut. Cara mengumpulkannya yaitu jam 7 pagi pasien mengeluarkan urine, urine ini dibuang. Semua urine yang dikeluarkan selama 24 jam, termasuk urine jam 7 pagi esok harinya, harus ditampung dalam botol urine yang tersedia (Gandasoebrata, 1969).

\section{Pemeriksaan Kalsium}

Dimasukkan $3 \mathrm{ml}$ urine ke dalam masing-masing 2 tabung reaksi. Tabung reaksi kedua dipakai sebagai kontrol. Kemudian, tambahkan kepada tabung pertama $3 \mathrm{ml}$ Reagens Sulkowitch, campur dan biarkan selama 2-3 menit. Amati kekeruhan yang terjadi. Kemudian, dibaca hasilnya.

\section{HASIL PENELITIAN}

Penelitian ini dilaksanakan pada bulan Juli tahun 2014. Sampel dikumpulkan di Jl. Balang Baru Kota Makassar dengan teknik pengambilan sampel Purposive Sampling. Sampel urine wanita lanjut usia 60 tahun ke atas sebanyak 10 sampel selanjutnya diperiksa di Laboratorium Akademi Analis Kesehatan Muhammadiyah Makassar. Hasil pemeriksaan disajikan pada tabel 1 .

Tabel 1.Hasil Pemeriksaan Kalsium Urine pada Wanita Lanjut Usia

\begin{tabular}{cccc}
\hline Sampel & $\begin{array}{c}\text { Usia } \\
(\text { Thn })\end{array}$ & Hasil & Keterangan \\
\hline A & 61 & + & Normal \\
B & 60 & ++ & Normal \\
C & 60 & +++ & Hiperkalsiuria \\
D & 61 & ++ & Normal \\
E & 63 & ++ & Normal \\
F & 61 & ++ & Normal \\
G & 62 & +++ & Hiperkalsiuria \\
H & 61 & + & Normal \\
I & 60 & +++ & Hiperkalsiuria \\
J & 60 & +++ & Hiperkalsiuria \\
\hline
\end{tabular}

Tabel 1. menunjukkan hasil
pemeriksaan kalsium urine yang bervariasi pada wanita lanjut usia di laboratorium Analis Kesehatan Muhammadiyah Makassar. Sebagian besar wanita lanjut usia di Jl. Balang Baru Makassar yang menghasilkan ekskresi kalsium normal sebanyak 6 orang, sedangkan Hiperkalsiuria sebanyak 4 orang (40\%). 
Tabel 2. Persentase

Hasil

Pemeriksaan Kalsium Urine pada Wanita Lanjut Usia

\begin{tabular}{|c|c|}
\hline Hasil Pemeriksaan & Jumlah \\
\hline Normal & $6(60 \%)$ \\
\hline Hiperkalsiuria & $4(40 \%)$ \\
\hline Jumlah & $10(100 \%)$ \\
\hline
\end{tabular}

Pada penelitian ini sampel yang digunakan adalah urine wanita lanjut usia di Jl.Balang Baru Makassar. Semua sampel yang diperiksa diambil atas persetujuan wanita lanjut usia dan diambil berdasarkan pertimbangan umur, kemudian diperiksa di laboratorium Kimia Klinik Akademi Analis Kesehatan Muhammadiyah Makassar.

Dari hasil pemeriksaan yang dilakukan diketahui bahwa sampel dengan kode A, B, D, E, F, dan H menunjukkan ekskresi kalsium pada urine yang normal, dimana kode sampel A dan $\mathrm{H}$ menghasilkan kekeruhan halus setelah ditambahkan reagen Sulkowitch yang berarti menunjukkan hasil (+1). Sedangkan kode sampel B, D, E, dan F menghasilkan kekeruhan sedang setelah ditambahkan reagen Sulkowitch yang berarti menunjukkan hasil (+2). sampel dengan kode $\mathrm{C}, \mathrm{G}$, I, dan $\mathrm{J}$ menunjukkan ekskresi kalsium pada urine yang tinggi, dimana menghasilkan kekeruhan agak berat yang timbul dalam waktu kurang dari 20 detik yang berarti menghasilkan $(+3)$, pada sampel ini menunjukkan hasil hiperkalsiuria. Sehingga hasil penelitian menunjukkan $60 \%$ wanita lanjut usia di Jl. Balang Baru memiliki urine normal sedangkan $40 \%$ lainnya menunjukkan hiperkalsiuria.

Hiperkalsiuria yaitu tingginya kadar Kalsium di dalam urine yang bisa disebabkan oleh tingginya pembuangan kalsium ke urine karena tingginya konsumsi kalsium atau bisa karena kurangnya jumlah urine yang dihasilkan. Karena jika urine yang dihasilkan semakin banyak, maka akan menurunkan konsentrasi kalsium di dalam urine sehingga mengurangi kepekatan urine oleh kalsium.
Berdasarkan faktor umur, diperoleh gambaran bahwa semakin tua usia wanita 60 tahun ke atas tidak menunjukkan bahwa semakin rendah kadar kalsium yang dimiliki. Hal ini menunjukkan bahwa ekskresi kalsium urine pada wanita lanjut usia tidak ikut dipengaruh oleh usia seseorang. Banyak pemicu yang dapat mempengaruhi rendah maupun tingginya ekskresi kalsium dalam urine seseorang antara lain yaitu kekurangan kalsium dalam tulang merupakan proses alami yag sulit dihindari sejalan dengan bertambahnya umur. Semakin tua semakin cepat tubuh menyerap kalsium dari tulang sebelum sampai digantikan. Wanita yang mencapai usia 60 tahun ke atas kadar kalsium dalam tulangnya akan menurun.

Ada beberapa pemicu lain yaitu terlalu banyak kalsium yang dikeluarkan melaui urine yang dapat menyebabkan terjadinya batu ginjal, konsumsi yang kurang selama jangka waktu tertentu. Asupan kalsium yang dikonsumsi juga mempengaruhi tinggi atau rendahnya ekskresi kalsium dalam urine (Almatsier, 2009).

\section{KESIMPULAN}

Berdasarkan hasil penelitian yang telah dilakukan, dapat disimpulkan bahwa 10 orang wanita yang telah lanjut usia terdapat $60 \%$ wanita yang telah lanjut usia orang menunjukkan ekskresi kalsium normal, dan $40 \%$ wanita yang telah lanjut usia menunjukan ekskresi kalsium tinggi.

\section{SARAN}

Berdasarkan kesimpulan tersebut, maka penulis memberikan saran sebagai berikut :

1. Bagi wanita lanjut usia hendaknya menjaga pola hidup, memperhatikan kebutuhan kalsium perharinya, dan mengkonsumsi makanan yang banyak mengandung kalsium

2. Bagi peneliti selanjutnya agar dapat meneliti gambaran kalsium urine dihubungkan dengan factor yang mempengaruhinya pada wanita lanjut usia. 
DAFTAR PUSTAKA

Almatsier S. 2009. Prinsip Dasar Ilmu Gizi. Jakarta: Penerbit PT.Gramedia Pustaka Utama.

Kalsium. Available from: http://id.wikipedia.org/wiki/Kalsi um.

Ma'rifatul, A. L. 2011. Keperawatan Lanjut Usia. Yogyakarta: Penerbit Graha Ilmu.

Gandasoebrata. 1999. Penuntun Laboratorium Klinik. Jakarta: Penerbit Dian Rakyat.

Guyton, A. C. 1990. Fisiologi Manusia dan Mekanisme Penyakit. Jakarta: Penerbit Buku Kedokteran EGC.

Muchtadi, D. 2009. Pengantar Ilmu Gizi. Bandung: Penerbit Alfabeta.

Muttaqin, A dan Sari, K. 2012. Asuhan Keperawatan Gangguan Sistem Perkemihan. Jakarta: Penerbit Salemba Medika.

Padila. 2013. Buku Ajar Keperawatan Gerotik. Yogyakarta: Penerbit Nuha Medika.

Sacher, R dan Mc. Pherson. 2004. Tinjauan Klinis Hasil Pemeriksaan Laboratorium. Jakarta: Penerbit Buku Kedokteran EGC.

Winarno, F.G. 1984. Kimia Pangan dan Gizi. Jakarta: Penerbit PT Gramedia Pustaka Utama. 